\title{
BRAZIL'S HANDLING OF COVID-19: A PERFECT STORM
}

Anderson da Costa Armstrong ${ }^{1}$

\begin{abstract}
In this opinion article, the experience of a professional in medicine and epidemiology is used to analyze data on the COVID-19 pandemic in Brazil and, more particularly, in its Northeast region. In these premises, a critical analysis is made about the crisis management generated by the pandemic, how science has been affecting public policies, aspects related to mathematical models used to justify restrictive public policies, regional measures of social isolation, the way in which the media has been disseminating information, and how the large volume of data on the pandemic can be translated into knowledge. More than a criticism of public policies, it is expected that the contextualized analysis will allow reflections that lead to a better crisis management, as generated by COVID-19 and future potential epidemics.
\end{abstract}

Key words: COVID-19, crises management, pandemic.

1 - MD MHSc PhD. Professor da Universidade Federal do Vale do São Francisco / Univasf. Email: armstrong_ac@icloud.com 


\title{
O ENFRENTAMENTO BRASILEIRO AO COVID-19: A PERFECT STORM
}

\begin{abstract}
RESUMO
Neste artigo de opinião, a experiência de médico e de epidemiologista é utilizada a fim de analisar os dados sobre o enfrentamento à pandemia do COVID-19 no Brasil e, mais particularmente, em sua região Nordeste. Nessas premissas, é realizada uma análise crítica sobre o gerenciamento da crise gerada pela pandemia, sobre como a ciência vem afetando as políticas públicas, acerca dos aspectos relacionados a modelos matemáticos usados para justificar políticas públicas restritivas, sobre as medidas regionais de isolamento social, sobre a forma como a mídia vem divulgando as informações e a respeito de como o grande volume de dados sobre a pandemia apresentados pode ser transposto em conhecimento. Mais que uma crítica às políticas públicas, espera-se que a análise contextualizada permita reflexões que levem a um melhor enfrentamento da crise gerada pela COVID-19 e de futuras epidemias potenciais.
\end{abstract}

Palavras-chave: COVID-19, gerenciamento de crise, pandemia. 


\section{INTRODUÇÃO}

Sayings often summarize analyses by joining multiple ideas and meanings synthetically. The English saying "a perfect storm" is used when a combination of negative circumstances arise simultaneously, bringing about unexpected catastrophic effects. When all is said and done, no single factor alone could cause a meteorological disaster. Wind, humidity, location, how the houses are built, the authorities' response, in short, a combination of factors that are not only meteorological generate the "perfect" conditions for the "storm" and the consequent catastrophe for humanity. This seems to me the most appropriate concept for describing the handling of COVID-19 that we are experiencing at this moment in Brazil.

As a cardiologist, my 15-year career has been divided between outpatient and hospital care, including intensive care environments. As a founder and preceptor of the Cardiology Residency Program of the Universidade Federal do Vale do São Francisco (Univasf), I have had the opportunity to evaluate a vast number of patients in the most diverse situations in our region. The São Francisco Valley is located in the Sertão region of the Northeast of Brazil, a thriving agriculture center inserted in one of the country's largest poverty belts. Involving several states on the São Francisco River, my professional activities are mainly concentrated in the states of Pernambuco and Bahia. The public and private healthcare services where I work represent highly complex medical services, and it is no coincidence that they are playing a central role in attending patients with COVID-19.

As a researcher, I have dedicated more than a decade of my work in Epidemiology, particularly in the areas of cardiovascular health and the health of Indigenous peoples, including my Master's (University of Pernambuco; Recife, Pernambuco, Brazil) and doctorate degrees (Bahiana School of Medicine and Public Health; Salvador, Bahia, Brazil), as well as my experience 
as a Fellow at Johns Hopkins University (Maryland, USA). I continue to work in the area, both teaching and developing scientific research.

In the beginning of 2020, it became clear to me that handling COVID-19 would be a totally new situation and that it would require the concentration of medical and scientific efforts and resources that would need to be recruited as soon as possible. It is not recommended to attempt to handle a completely new pandemic situation without considering regional peculiarities. The epidemiological triad, on which this science is wholly based, lies in aspects related to the pandemic agent, the human hosts, and the environment where the disease will evolve. Diverse groups of humans and different regions will require specific viewpoints; it is not possible to deal with an entire continent, a country, or even a state uniformly.

For approximately four months, I have, therefore, dedicated most of my activities to studying COVID-19 and to handling the disease from an epidemiological, medical, and scientific point of view. Currently, I preside over the Commission responsible for elaborating, following up on, and monitoring actions to prevent the coronavirus at Univasf; I am a member of the Committee for handling COVID at UNIMED Vale do São Francisco, and I represent Univasf in the Committee for Combating COVID-19 made up of various commercial entities in the city of Petrolina, Pernambuco, in addition to participating in strategic groups for handling the disease that include federal, state, and municipal authorities. In addition to this, I continue to attend patients with suspected or confirmed COVID-19, with a special focus on cardiovascular conditions underlying or consequent to COVID-19, and I am involved in developing scientific research projects that help explain the behavior of this novel disease.

In this editorial, I intend to discuss the handling of COVID in a manner centered on personal experience and on the available scientific data. COVID-19 is so new that the volume of robust scientific evidence thereon is still very scarce, especially with respect to Brazil and the Northeast Region. Organizing 
ideas of people who, like me, are involved in several frontlines and who are seeking to deepen scientific knowledge may, in a certain manner, contribute to our understanding of the disease. Accordingly, I hope to clarify my opinion with respect to the "perfect storm" to which the title refers.

\section{RECOGNIZING AND MANAGING THE CRISIS}

Considering the biological risk posed by the COVID-19 pandemic, the crisis may be considered as installed in situations where there are abnormalities and severity in a given situation, which translate as uncertainty regarding the development of the situation and inability to act against these processes. Within this scenario planning and operationalization of actions to manage the crisis must follow a continuous flow that allows for decision making and prompt implementation (LOURENÇO, 2003).

In Brazil, it seems to me that many aspects that are relevant to decision making in crisis management during the COVID-19 pandemic adhere predominantly to criteria that are more political than technical. The important role of this "politicization" may be attributed to the upcoming municipal elections scheduled for the second half of 2020 and the consequent fomenting of political protagonism peculiar to these occasions. But closer observation will show us that a significant portion of administrators on federal, state, and municipal levels have demanded efforts to prevent the progression of infection and to increase the number of beds with the purpose of handling the disease. Thus, in my opinion and experience, the main problem in managing this pandemic crisis has been difficulties in coordinating actions for handling the disease.

It is worth noting that the potential dangers which a crisis could generate were recognized early on. Ordinance 188 of the Brazilian Ministry of Health, on February 3,2020 , decreed a state of emergency in national public health as a result of the COVID-19 pandemic (BRASIL, 2020). All the same, we did not see widespread public policies to prevent the spread of the disease during the period of Carnival, from February 21 to 26 , which is generally known to be a 
Revista Científica do Corpo de Bombeiros Militar de Pernambuco

Artigo Publicado no Vol.06 N.16 - Edição Especial 2020 - ISSN 2359-4829

Versão on-line disponível em: http://www.revistaflammae.com

moment of large gatherings and physical contact. Curiously, the first case in Brazil was confirmed precisely during Carnival, on February 25. The lack of coordinated measures on the part of sanitary authorities during the period of Carnival especially drew my attention, as I work in the states of Pernambuco and Bahia, which have rich traditions of crowded events in the streets, and because I am also fond of the Carnival festivities.

When we look at the cases of severe acute respiratory syndrome (SARS) monitored by FIOCRUZ (Figure 1), we may observe that, precisely during the ninth epidemiological week of 2020 (when Carnival took place), cases of SARS (the solid black line in Figure 1) had already begun to exceed the pre-epidemic monitoring line (the lime green dotted line). This means that, during this period, notifications of SARS were already higher than expected, considering the average of several years of monitoring by FIOCRUZ. The following week, escalation of new cases is visible, and it follows an exponential trend (Figure 1).

Figure 1 - Incidence curve of severe acute respiratory syndrome in Brazil, according to monitoring by FIOCRUZ.

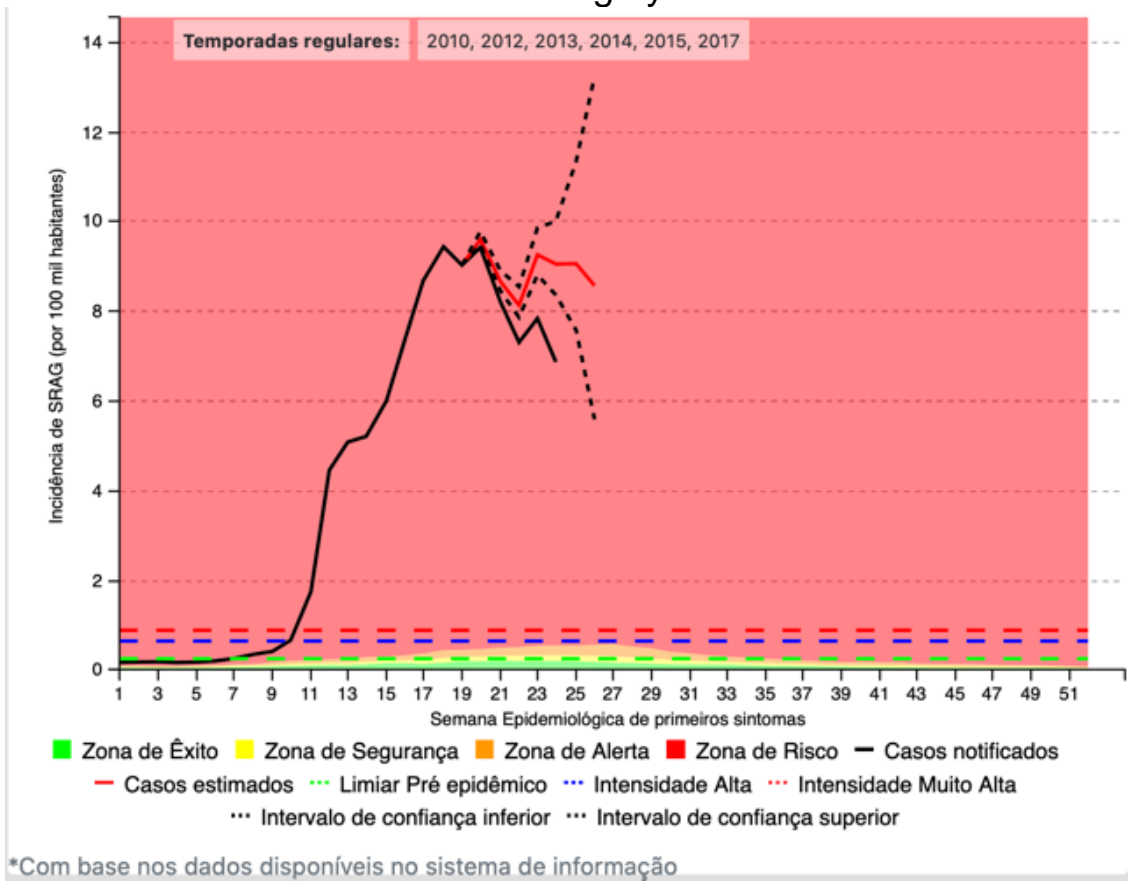

Legend: FIOCRUZ, 2020 (access in 02/07/2020). 


\section{Revista FLAMMAE}

Revista Científica do Corpo de Bombeiros Militar de Pernambuco

Artigo Publicado no Vol.06 N.16 - Edição Especial 2020 - ISSN 2359-4829

Versão on-line disponível em: http://www.revistaflammae.com

SARS is a respiratory condition generally associated with severe pneumonia caused by viruses such as influenza or the novel coronavirus. It is not possible to affirm categorically that the cases notified and monitored by FIOCRUZ, described in Figure 1, are all due to COVID-19. That would require specific tests in patients who were hospitalized in order to determine the type of virus. As previously stated, there were no mass testing policies during the period of Carnival, which makes it impossible to be certain regarding the role of the novel coronavirus in this scenario. It is worth underscoring, however, that, during the COVID-19 pandemic, moreover during the period which the Ministry of Health had already recognized as dangerous, it is highly likely that the majority of SARS cases notified to FIOCRUZ are directly related to COVID-19.

The example of Carnival, owing to the magnitude of the event in relation to Brazil's culture and economy, demonstrates that there have been failures in communication and management of the COVID-19 crisis from the beginning of the pandemic. They did not end there. Key positions in the Ministry of Health have been frequently changed; politicians with no training in health have discussed the particularities of prescribing determined medications; various spheres of government have publicly and even judicially disputed the limits of their sovereignty regarding actions against COVID-19; diverse groups of people have taken to the streets in rallies for their political convictions, and, in the midst of political party ideals, this has generated a coordination vacuum for managing the COVID-19 crisis.

Inadequate management of COVID-19, thus, constitutes an element that formed the "perfect storm" to which the title refers. It is worth underscoring that, in my opinion, it is not possible to put forth resounding criticism of any specific measures which healthcare administrators have implemented in good faith to combat COVID-19. Everything is so new that it would not be appropriate to propose a "cake recipe" of measures to be adopted. The criticism lies in the precarious manner in which the crisis has been and, in many measures, continues to be recognized and managed. 


\section{SCIENCE AND PUBLIC POLICIES: "The first casualty of war is truth" (attributed to the United States senator Hiram Warren Johnson, in 1918)}

Famous quotations in English frequently come to mind as I write this typically Brazilian article. There are several aspects that lead me to compare the handling of COVID to periods of war: empty streets, stagnating economy, impending poverty, people living in terror, images of mass graves in the media, healthcare professionals who are on the frontlines of combat being applauded in urban centers, ideological clashes, direct and indirect victims. We healthcare workers find ourselves in intimate conversations that seem more like battle stories; we are directly affected, and we end up taking the burden home to our families.

"Truth," on the other hand, may be seen as a philosophical concept which I would not risk discussing in this article. Almost as profound and subjective is the concept of "scientific integrity," which is the closest means for scientists to reach "truth." Scientific integrity is based on researchers' honesty (Yes! The overwhelming majority of researchers are honest, based on my experience in Brazil and abroad). This refers to honesty with respect to their pre-specified scientific objectives, the rigor and adequacy of the methods of scientific investigation, the proportional testing of conclusions in relation to their findings, the thorough criteria-based peer review of scientific research before it is published, and the responsible sharing of available scientific evidence.

Unfortunately, scientific integrity does not appear to be at its highest during the COVID-19 pandemic. Some of the most highly renowned magazines, such as The Lancet and The New England Journal of Medicine, have published articles with questionable data, in an accelerated manner bordering on negligence which subsequently obliged them to issue public retractions (MEHRA, et al. 2020a; MEHRA, et al. 2020b). 
Even in publications whose data are not questionable, an avalanche of observational or even experimental studies are being presented as solid justification for given therapies, without adequate studies truly providing answers. Many scientists and healthcare professionals seem to have forgotten that Epidemiology and Medicine are in themselves sciences of probability, rather than exact sciences, and they have chosen to aggressively defend their ideas, held as true, in media of communication, even though most of them are built on sandy scientific grounds.

Scientific honesty lies not in defending the scientific "truth," but rather in recognizing the limitations of studies, positioning conclusions proportionally to the findings, within their context and the possible controversies which exist in the most current scientific knowledge. It is my understanding that anyone who claims to be absolutely certain regarding conduct in any case of COVID-19 at this moment is wrong. These are times of doubt that call for individualization of therapeutic conduct according to each case's presentation.

\section{OVERESTIMATING MATHEMATICAL MODELS AT THE ONSET OF THE CRISIS}

An interesting aspect, which is also linked to scientific integrity in a certain manner, is what appears to me as the recent overestimation of mathematical models for predicting cases and deaths. Shared as absolute truth during the beginning of the pandemic, they led to countless measures of social restriction and caused panic through new virtual media and even traditional journalism. Charismatic Youtubers and self-proclaimed journalists treated them as incontestable, leaving no room for controversy.

Initially, the media widely disseminated data from the mathematical model produced by the Imperial College of London at the onset of the pandemic, which predicted several epidemic scenarios for Brazil, ranging from a minimum of 270,693 deaths in the event that the most restrictive social 
distancing measures were adopted to a total of 1,152,283 deaths in the event that no measures were adopted (WALKER et al. 2020)

These numbers seemed paramount to a good number of epidemiologists. We typically use mathematical models to generate predictions; their basic premise is the fact that mathematical models need to be constructed on variables that are arbitrarily selected and elaborated by the people who build the models. Naturally, the more we know about a disease and the factors that affect its transmissibility and lethality, the closer we may come to computing a real situation. For this reason, mathematical models are valuable, but they must be interpreted within the bounds of their limitations and revised as our understanding of a disease advances. We witnessed the automatic acceptance of mathematical models as absolute truth and their numbers as scientific truth without room for dispute, which even led to questions being raised regarding the scientific integrity of their most staunch advocates (CIURIAK e FAY, 2020).

For an absolutely novel disease like COVID-19, it would be natural for the mathematical models to be outside of reality in their initial affirmations. In fact, the predicted calculations for the number of deaths initially proposed, which had a great impact during the beginning of the pandemic, do not come close to the official numbers of Brazil's Secretary of Health Surveillance/Ministry of Health, namely, 57,070 deaths, updated on June 27, 2020 at 7:00 pm and published in Special Epidemiological Bulletin number 20 of the Ministry of Health.

\section{SOCIAL ISOLATION MEASURES IN BRAZIL AND THE NORTHEAST REGION}

These allegedly indisputable mathematical models also promoted social isolation measures, or lockdown, as the salvation in handling COVID-19. In the general population's perception, the idea that staying home could definitively and effectively prevent them from contracting COVID-19 has solidified. Some clarifications, however, are warranted in this regard. 


\section{Revista FLAMMAE}

Revista Científica do Corpo de Bombeiros Militar de Pernambuco

Artigo Publicado no Vol.06 N.16 - Edição Especial 2020 - ISSN 2359-4829

Versão on-line disponível em: http://www.revistaflammae.com

First, in spite of effects of social distancing which are still unknown in the context of COVID-19, reports of the 1918 Influenza Pandemic, analyzed by the World Health Organization in 2006, indicate that social distancing measures did not stop or appear to drastically reduce the transmission of influenza during this period (WORLD HEALTH ORGANIZATION WRITING GROUP, 2006).

There is, in fact, little evidence on the effectiveness of social distancing measures in mitigating the transmissibility of influenza as a whole, considering its historical evolution. When employed, these measures aim to prevent all people from being sick at the same time rather than protecting them indefinitely. As a result, social distancing can be effective by allowing us to buy time in order to produce enough vaccines or to avoid the collapse of healthcare systems dealing with a major influx of severely ill people (OSHITANI, 2006).

We are, thus, dealing with the endeavor, which is so widespread in the media, to "flatten the curve" of COVID-19 transmission (Figure 2A). This is due to the fact that isolated people who are susceptible, as long as there is not an effective vaccine, will be subject to becoming infected and developing the disease once isolation measures are relaxed, thus leading to a plateau or even new peaks of cases (WORLD HEALTH ORGANIZATION WRITING GROUP, 2006).

Figure 2- Graphs related to social distancing in COVID-19: A - representation of

"flattening the curve" of transmission; B - daily deaths due to COVID-19 (7-day average), by number of days since the first record of 3 daily deaths. The star indicates the moment when lockdown was decreed in each country.

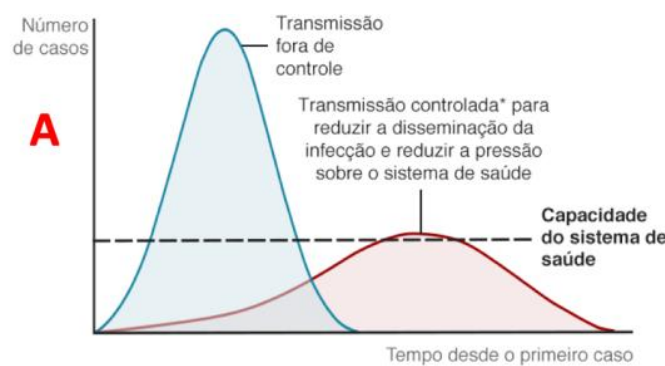

"Com medidas como orientar higiente adequada das mãos, adotar trabalho remolo, limitar eventos públicos e restringir viagens internacionais

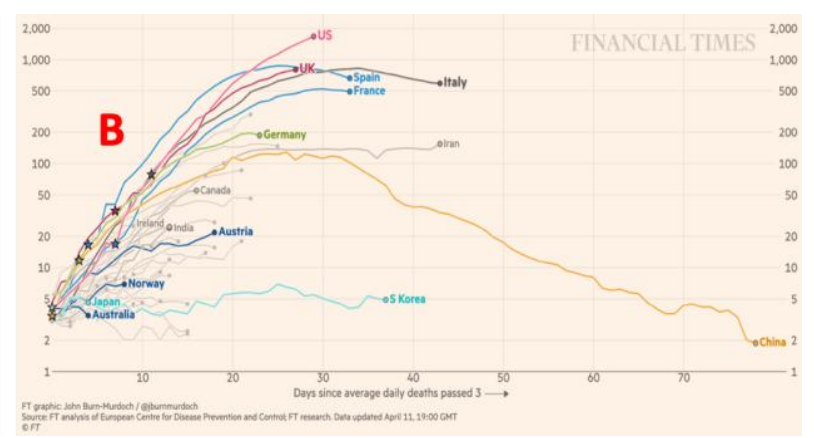

Source: (A) - BBC Internacional - 51850382 - access in 03/04/2020;

(B) - Financial Times coronavirus-latest - access in 12/04/2020 
The impact of isolation measures on COVID-19 is still not truly known. Diverse countries have adopted measures with varying degrees of social restriction and at different phases of the pandemic, and this has not clearly affected the evolution of deaths in each country (Figure 2B). Just as the value of lockdown is not totally clear, it not is evident when this measure should be attempted and how it would be subsequently relaxed, especially considering a scenario where mass vaccination is not available.

Brazil has experimented with poorly articulated measures between different levels of government in order to adopt social isolation. In the region where I live, I have witnessed cities divided by only a bridge with regulations and adherence to social isolation that have been distinct during most of the pandemic, to date. In addition to this, there are disagreements between municipal and state policies and between state and federal policies. Given that the objective most commonly espoused by administrators is to prevent the healthcare system from collapsing, clear criteria regarding occupation of hospital beds have not been established to determine levels of isolation. In reality, it feels as though actions are predominantly moved by fear, nonprofessional social pressure, and political party ideologies, rather than by clearly technical attitudes.

In fact, countries such as India, which have a typically high number of inhabitants per household, seem to have, for reasons that are not entirely clear, even witnessed an increase in number of cases after lockdown was decreed (PULLA, 2020). Moreover, data from the state of New York, published in May 2020 show that $66 \%$ of people recently admitted to regional hospitals due to COVID-19 claimed that they were sheltering at home when they contracted the disease, and $18 \%$ came from elderly care homes (SPECTRUM NEWS NY, 2020).

The data per se do not make it possible to exalt or condemn social isolation measures. They do, however, make it possible to question those who 
see this measure as the only salvation. It is more likely that diverse social isolation measures have limited impacts that are directly related to regional characteristics, such as number of inhabitants per household, demographic density, and number of inhabitants in large buildings, for example. In this context, social isolation measures may be considered for managing the current biological crisis, in conjunction with others measures of hygiene, etiquette, and individual protection.

What is undeniable is that these social isolation measures need to be better planned and coordinated. Rule number one of Medicine in Hippocratic teaching is "Primum non nocere" (First, do no harm). All medical conduct necessarily entails a certain degree of risk of adverse effects. Epidemiological social distancing measures, in their turn, are not free from undesirable side effects.

Human beings are, after all, social beings, and isolation tends to be prejudicial to mental health, with consequences that are still uncertain. It is certain that interrupting economic activities has an impact on the nation's productive sectors. Poorer regions, such as the Sertão in the Northeast of Brazil, are even more susceptible to great damage as a result of the abrupt deceleration of the economy. Regional contextualization and coordination with the establishment of clearer criteria seem to me to be the most rational way to adopt distancing measures, thus seeking to minimize their harmful effects and maximize their potential benefits.

\section{THE CULT OF FEAR: HOW DATA MAY PRODUCE MORE FEAR THAN INFORMATION}

The media, in turn, often opt to present select data with a more sensationalist character, which contributes to generating fear and misinformation, with part of the population rushing to pharmacies in search of 
life-saving medications and the dissemination of half-truths that in no way contribute to handling the crisis.

Showing data makes journalism more reliable. The manner in which data are shown to populations that are not prepared to interpret them, however, directly influences people's perception in relation to the real crisis situation and how it progresses over time. Data that are shown without contextualization, proportional interpretation, or even the right to dispute lead to biased public opinions tending toward pessimistic perception of the context produced by COVID-19.

One instance which seems to me particularly widespread in the media is the presentation of cumulative data, to the detriment of new cases (incidence) and comparison between locations in terms of absolute numbers rather than numbers in proportion to the population (mortality). These numbers have been substantially presented in television programs that expose them without a proper scientific context that would support proper interpretation.

Let us observe graphs (Figure 3 ) from the online data platform Our World in Data (ourworldindata.org), which is used by the Brazilian Ministry of Health as a data source. Data on deaths may be presented cumulatively (Figure 3A), which will produce graphs that are always increasing, given that they deal with the sum of deaths. Cumulative graphs do give us an idea of the disease burden on the population, but they do not exactly help us understand the behavior of the disease. In order to do this, data on incidence (Figure 3B), new cases, offer better information. Note that the cumulative graph (Figure $3 A$ ) will always increase, whereas incidence data (Figure 3B) show earlier deceleration trends and even decreases. 
Figure 3 - Graphs of deaths in Brazil: A - cumulative deaths; B - new deaths recorded (incidence)

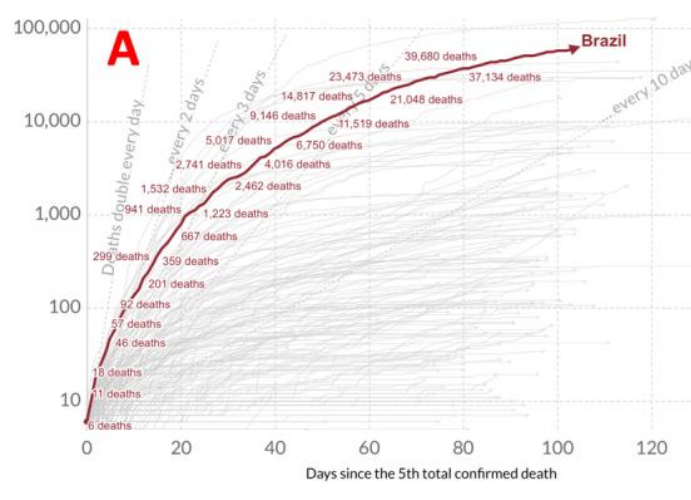

Source: Our World in Data, 2020

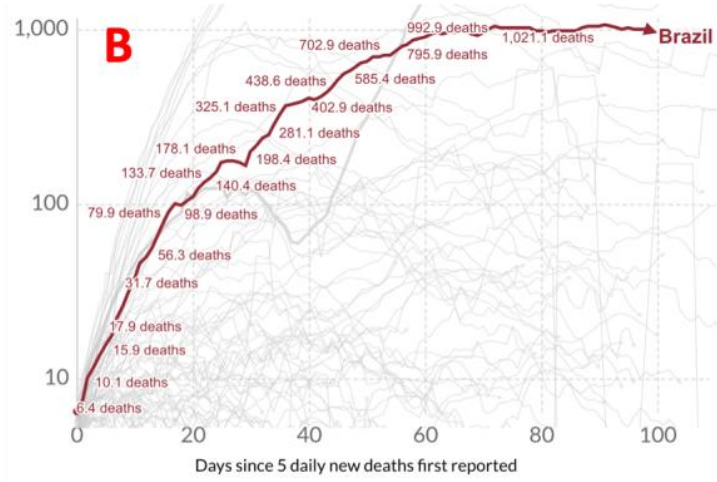

Source: European CDC - Situation Update Worldwide - Data last updated 2nd Jul, 08:45 (GMT-0:3

Figure 4 provides an example of how comparisons between countries might be shown regarding number of deaths caused by COVID-19, based on graphs produced by the Financial Times (www.ft.com/coronavirus). Comparison of new deaths between countries in terms of absolute numbers (Figure 4A) shows Brazil in a situation that seems more severe in relation to other countries than when these same deaths are taken into consideration in proportion to the populations of each country analyzed (Figure 4B). Brazil's situation seems even worse when comparing the absolute number of cumulative deaths (Figure 4C) than when comparing the same number of deaths in proportion to the population of each country (Figure 4D). 
Revista Científica do Corpo de Bombeiros Militar de Pernambuco

Artigo Publicado no Vol.06 N.16 - Edição Especial 2020 - ISSN 2359-4829

Versão on-line disponível em: http://www.revistaflammae.com

Figure 4 - Graphs of deaths comparing countries: A - new deaths in absolute numbers; $\mathrm{B}$ - new deaths per million inhabitants; $\mathrm{C}$ - cumulative deaths in absolute numbers; D - cumulative deaths per million inhabitants

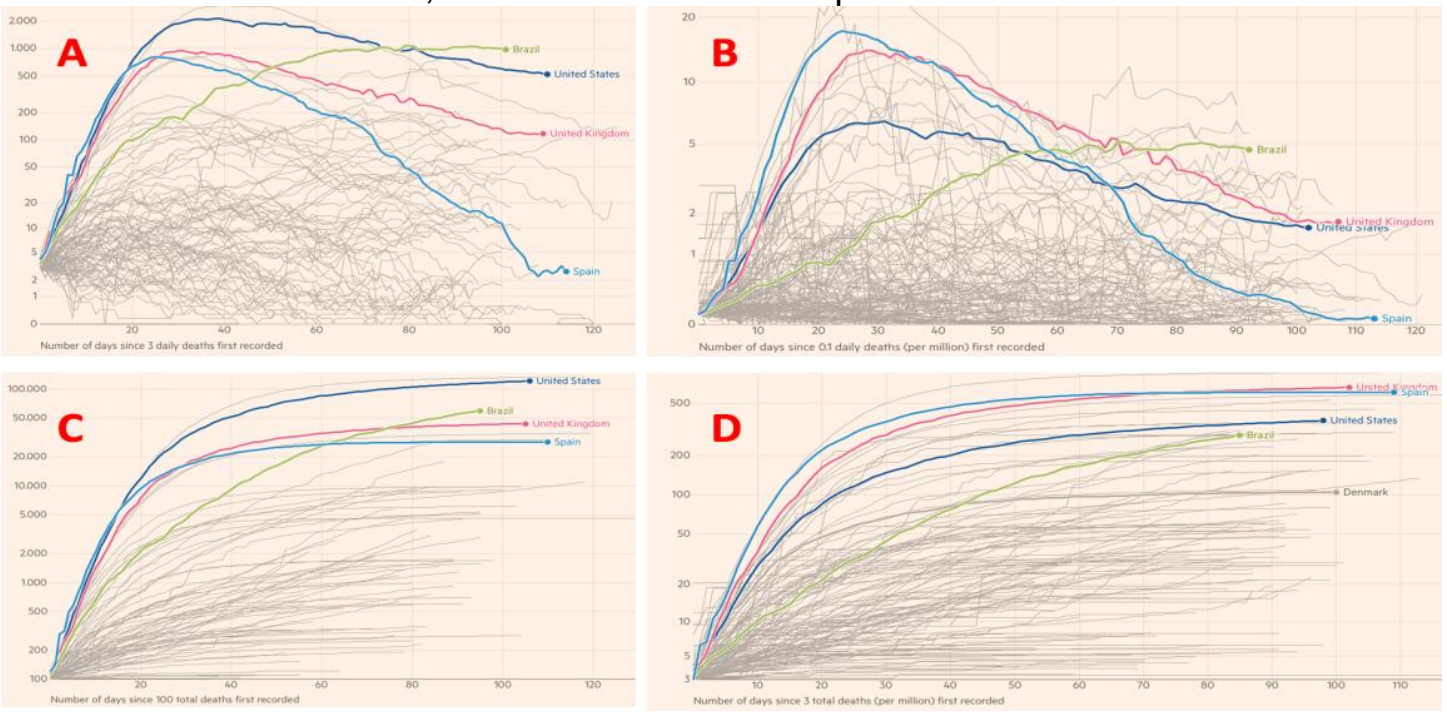

Source: Financial Times, 2020.

\section{DATES OF CONFIRMED CASES AND DEATHS EQUIVOCALLY INTERPRETED TO ESTABLISH EPIDEMIOLOGICAL MOMENT}

We must keep in mind that, once an individual is infected with the novel coronavirus, he or she will spend approximately five days without showing symptoms. Starting with the first days of symptoms, he or she will spend approximately seven more days in the first phase of the disease, namely, viral replication. After the seventh to tenth day, the individual tends to go on to present a phase which is less determined by the presence of the virus per se than by his or her own organism's inflammatory reaction. It is during this phase that more severe respiratory syndromes tend to present and lead to hospitalization. Hospitalizations due to COVID-19, in turn, tend to be delayed. Deaths, for example, tend to occur around the tenth to fourteenth day of hospitalization. In this manner, a death due to COVID-19 in the ICU, in general, represents a person who has been infected for more than twenty days. 
Confirmation of cases of COVID-19, on the other hand, is basically done in the following two manners: by detection of RNA of the virus during the first phase of symptoms of the disease (considered the gold standard) or by detection of antibodies against the virus, which occurs 10 to 14 days after onset of symptoms. The type of exam performed will depend on the moment when the person is investigated and, of equal importance, on the availability of tests, which is extremely unequal in Brazil.

For instance, the public healthcare network in Pernambuco and Bahia, in both cases, has the methods for detecting the virus in only one central laboratory in the respective states' capital cities, in order to attend the entire state. Measures are underway in order to amplify this availability, many of which are partnerships with public universities, such as Univasf. In the meanwhile, there continues to be a major bottleneck in releasing exams, which means that deaths due to COVID-19 are only confirmed about two weeks after they occur.

These aspects are of the highest importance for two main reasons. First, Brazil, especially the Northeast, has limited resources for mass testing of the population. As a result, the majority of mild cases are not tested or they undergo rapid tests, which have more limited accuracy than detection of viral RNA and which reflect a disease contracted 15 to 20 days before the test. This leads to underreporting of new cases and overestimation of lethality (which represents the number of people who contract the disease and consequently die) of COVID-19 in our region.

In contrast, virtually all cases of suspected deaths due to COVID-19 are properly tested. Nevertheless, delays in releasing data and fluctuations in activities throughout the week lead to these data frequently being interpreted in an equivocal manner. Figure 5 shows graphs developed from Special Epidemiological Bulletin number 20 of the Brazilian Ministry of Health, on epidemiological week 26 (21 to 27/06/2020). 


\section{Revista FLAMMAE}

Revista Científica do Corpo de Bombeiros Militar de Pernambuco

Artigo Publicado no Vol.06 N.16 - Edição Especial 2020 - ISSN 2359-4829

Versão on-line disponível em: $\underline{\text { http://www.revistaflammae.com }}$

Figure 5. A - number of cases of COVID-19 per million inhabitants (incidence rate); B number of deaths due to COVID-19 per million inhabitants (mortality rate); $\mathrm{C}$ - deaths due to severe respiratory syndrome related to COVID-19, by date of death
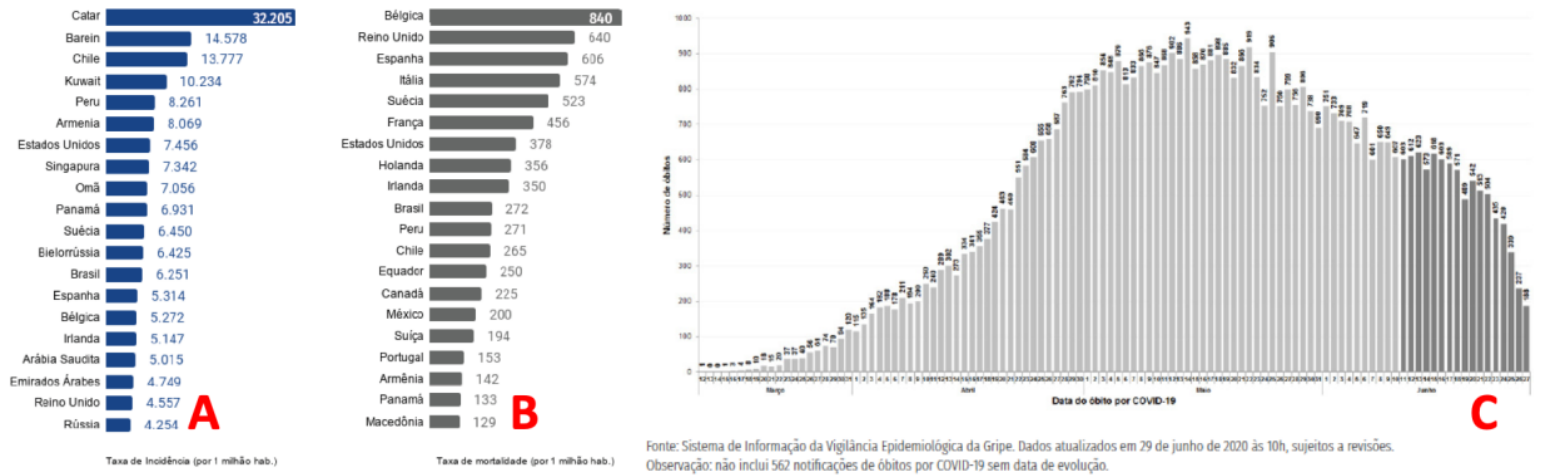

Figure $5 \mathrm{~A}$ shows the number of confirmed cases in relation to the number of inhabitants of each country. It is worth noting that Brazil holds thirteenth place in this ranking, but it climbs to tenth place in mortality (Figure 5B). This is largely due to our degree of underreporting of mild cases, leading Brazil to have a lower number of confirmed cases per inhabitant. In contrast, Brazil's mortality is a more trustworthy piece of data, given more effective testing. Figure $5 \mathrm{C}$ shows that, when we analyze deaths by date, we conclude that the peak number of deaths occurred during the first half of May 2020, mainly swayed by numbers from São Paulo and its population representativeness. These were people who contracted the disease between the end of April and the beginning of May 2020.

It is interesting that COVID-19, in Brazil, begin in capital cities, and, at this moment, has gone of to transition toward the interior. Nonetheless, the population representativeness of capital cities largely exceeds that of cities in the interior, especially in the Northeast Region. With this in mind, the national peak should have initially been overcome. While the increase in deaths was rapid, the decrease may be more gradual, considering the migration of cases to diverse regions of the country.

\section{FINAL CONSIDERATIONS}

Brazil is a continent-sized country, with significant regional characteristics, which probably impact the epidemiology of COVID-19 in our territory. The 
reflections put forth in this article should not be seen as pointed criticism but rather as a form of conjectural contextualization so that medical and sanitary technical aspects are given priority and properly put into practice in the context of more effective crisis management during the rest of this first wave of COVID19 contagion, during potential future waves of COVID-19, and during potential future biological crises.

In conclusion, the novel coronavirus has come and it will likely continue circulating among human beings, possibly due to new outbreaks, until there is more effective control (most likely when effective mass vaccination becomes a reality). This is, moreover, not the first pandemic humanity has faced, and it certainly will not be the last.

\section{Acknowledgments}

My sincere thanks to Robert Bradley Smith, of the company 4 Sílabas (smithrobertbradley@gmail.com), for translating this article into English free of charge, as part of his personal policy of voluntary contribution to combating COVID-19.

\section{Disclaimer}

The author finalized this article between July 1 and 2, 2020. For this reason, unless expressly stated, the websites cited were evaluated during this period.

The author expresses, in a partial manner, the scientific ideas addressed here on social media and on his Youtube channel, Cardiodebug <https://www.youtube.com/channel/UC2ITD7pK5FmTJPIr-SYQIEQ>.

The figures shown here were not created by the author of this article, but they are freely accessible on the Internet, as shown, and their authors have been cited in the text. The author leaves the editors of the magazine in charge of any additional authorizations which they may deem pertinent. 


\section{REFERENCES}

BRASIL (Ministério da Saúde). Declara Emergência em Saúde Pública de importância Nacional (ESPIN) em decorrência da Infecção Humana pelo novo Coronavírus (2019-nCoV).Portaria n.188, de 03 de Fevereiro de 2020.

CIURIAK, Dan; FAY, Robert. The Critical Numbers Game: How Models can Inform the Pandemic Policy Response from Lockdown to Reboot. Opinion, Centre for International Governance Innovation, v. 28, 2020. Disponível em: $<$ https://medium.com/@wpegden/a-call-to-honesty-in-pandemic-modeling5c156686a64b - acessado em 12/04/2020>.

FIOCRUZ (Fundação Oswaldo Cruz). Monitoramento de casos reportados de síndrome respiratória aguda grave (SRAG) hospitalizados, 2020.

GROUP, World Health Organization Writing. Nonpharmaceutical interventions for pandemic influenza, national and community measures. Emerging infectious diseases, v. 12, n. 1, p. 88, 2006. Disponível em: $<$ Nonpharmaceutical Interventions for Pandemic Influenza, National and Community Measures. WHO. Emerg Infect Dis. 2006 Jan; 12(1): 88-94>.

LOURENÇO, Luciano. Análise de riscos e gestão de crises. O exemplo dos incêndios florestais. Territorium, n. 10, p. 89-100, 2003.

PULLA, Priyanka. Covid-19: India imposes lockdown for 21 days and cases rise. 2020.

SPECTRUM NEWS NY. New Survey Suggests 66 Percent of All New Hospitalizations Statewide Are From People Sheltering at Home, 2020. Disponível em: <https://www.ny1.com/nyc/all-boroughs/news/2020/05/07/newsurvey-suggests-66--of-all-new-hospitalizations-are-from-people-sheltering-athome->.

MEHRA, Mandeep R. et al. Hydroxychloroquine or chloroquine with or without a macrolide for treatment of COVID-19: a multinational registry analysis. The Lancet, 2020a. Disponível em: <https://www.thelancet.com/journals/lancet/article/PIIS0140-6736(20)311806/fulltext\#articlelnformation>

MEHRA, Mandeep R. et al. Cardiovascular disease, drug therapy, and mortality in COVID-19. New England Journal of Medicine, 2020b. Disponível em: <https://www.nejm.org/doi/full/10.1056/NEJMoa2007621>. 


\section{Revista FLAMMAE}

Revista Científica do Corpo de Bombeiros Militar de Pernambuco

Artigo Publicado no Vol.06 N.16 - Edição Especial 2020 - ISSN 2359-4829

Versão on-line disponível em: http://www.revistaflammae.com

OSHITANI, Hitoshi. Potential benefits and limitations of various strategies to mitigate the impact of an influenza pandemic. Journal of Infection and

Chemotherapy, v. 12, n. 4, p. 167-171, 2006. Disponível em: <Potential benefits and limitations of various strategies to mitigate the impact of an influenza pandemic. Hitoshi Oshitani. J Infect Chemother (2006) 12:167-171>

WALKER, Patrick et al. Report 12: The global impact of COVID-19 and strategies for mitigation and suppression. 2020. Disponível em: $<$ https://www.imperial.ac.uk/media/imperial-college/medicine/sph/ide/gidafellowships/Imperial-College-COVID19-Global-unmitigated-mitigatedsuppression-scenarios.xlsx>. 
